\title{
The Impact of Transformational Leadership Style On Employee Job Performance: The Mediating Effect of Training
}

\author{
Fatma Nasser Al-Harthy ${ }^{1}$, Prof. Nor' Aini Yusof ${ }^{2}$ \\ ${ }^{1,2}$ School of Housing, Building and Planning, Universiti Sains Malaysia
}

\begin{abstract}
Changes in Oman's economy have brought to the fore opportunities and challenges to the Omani construction industry as qualified and skilled labour is required to serve the Sultanate's rapid developments. This study investigates the impact of the transformational leadership style on employees' job performance by introducing capable graduates to the construction sector in Oman. It also investigates the mediating effect of employee training experience between transformational style and employee performance at Omani Colleges of Technology. The sample of this study was 175 construction employees in Technical Colleges in Oman. Data were gathered via questionnaires to achieve the objective of this research. The data were analyzed using Smart PLS. The study findings confirmed that the prediction of the transformational leadership style is positively related to employee training. Also, employee training is positively related to employee job performance. In this research, empirical results significantly supported that employee training mediated the relationship between transformational leadership style and employee job performance.
\end{abstract}

Keywords: transformational leadership, employee job performance, training, experience, Omani Colleges of Technology

\section{Introduction}

Due to the boost in the industry of oil production, the Sultanate of Oman is witnessing vast and rapid growth in its economy. With many flourishing projects, the construction industry sector in particular has been witnessing a massive urban boost (Saleh, 2015). "The pressure of modernization and urbanization has induced positive growth in the Oman's construction sector especially in infrastructure development" (Abidin \& Powmya, 2014:1). Therefore, opportunities and challenges have emerged as the Omani construction industry requires various types of skills and qualifications of its labour so that they can effectively participate in catching up with the Sultanate's latest developments and the GCC in the construction sector in particular (Al-Lamki, 2002; Ewers, 2015). One essential factor, which guarantees the success of an organization, is leadership. Leadership is also argued by (Vigoda-Gadot, 2007) that it is considered as a key element in the performance of an employee organization. There is an emphasis on educational leadership in particular, whereby leaders in educational organizations are significant and influential due to their role in making the future of a society. Therefore, educational institutions do need good and skilled leaders. Efficient leadership is crucial in running these institutions in the complicated, globalized environment (Altbach, 2011). The recent shift in the construction industry worldwide and changing norms in the workplace, coupled with globalization and the emergence of new technology demand highly skilled employees, who have the ability to adapt, embrace and implement the change (Audu, Kamin, \& Saud, 2013). The industry today is concerned about tapping qualified and skilled employees who are be able to adapt according to the needs of the working environment. However, the paradoxical situation is that graduates of technical colleges are unfortunately not familiar with such a phenomenon. Therefore, they are unable to apply their academic learning into real-life working environments.
Transformational leadership represents the independent variable, it is supposed to be significantly related to employees' performance, which is the dependent variable (Vigoda-Gadot, 2007 \& Wang, Law, Hackett, Wang \& Chen, 2005). This leadership style is also considered to be significantly related to the training experience (Wang \& Berger, 2010; Al-Lamki, 2006; Akhavan \& Abu, 2009). In this study, the training experience is proposed to be the mediator variable. There exists a positive relationship between employee performance and training experience (Nasazi, 2013; Afshan, Sobia, Kamran, \& Nasir, 2012). Thus, this study, focuses on the transformational leadership style with regard to academic employees' performance and their effect on producing graduates from Omani colleges of technology, who are highly skilled and well qualified to suit the construction industry sector. To contribute to the Sultanate's ongoing economic development, the Omani government is planning to prioritize technical education for the Omani students and employers as well. This can be done through the provision of good teaching, learning and research. The Sultanate of Oman strives to generate graduates of high professional skill so that they will participate in the Sultanate's economic growth (Lamloumi, 2013).

\section{Employee Performance}

In most theories on management and organizational psychology, employee performance is basically used as one important dependent variable, which affects organizational goals (Kalbers \& Cenker, 2008). Employee performance is regarded a key factor, which leads to organizational performance (Beletskiy, 2011). Employees who performed well, assist organizations to remain competitive and achieve strategic goals. Employee performance is linked to employees possess the knowledge about their work, objectives and capabilities to meet the work standard formed by their organization. The performance of employees is a key work outcome in organizational studies. Kalbers and Cenker (2008) 


\section{International Journal of Science and Research (IJSR) \\ ISSN (Online): 2319-7064}

Index Copernicus Value (2013): 6.14 | Impact Factor (2015): 6.391

indicated that employee performance is an important work outcome. Employee performance can be divided into task performance and contextual performance. Task performance is an essential requirement of an employee's role, which should be identified by job analysis (Greenslade \& Jimmieson, 2007). Meanwhile, contextual performance is viewed as the individual contribution that does not directly influenced their main tasks, but is equally important to the development of the organizational, social and psychological context. According to what has been mentioned previously, employee performance is seen as a key factor contributing to organizational performance. It also reflects the real performance of the employees.

\section{Transformational Leadership Style}

The importance of transformational leadership has emerged since 1970s due to the major changes in the international economy and large companies. There are four elements of transformational leadership style: intellectual stimulation, individualized consideration, inspirational motivation, and idealized influence. Bass (2005) was credited for popularising and developing the transformational style, which is based upon passion, charisma and inspiration. Transformational leadership articulates a compelling vision and conviction that their dreams can be achieved through strategic planning and execution. Leaders don't also inspire and develop followers, but also create more leaders to form a core management team to help drive organizational performance. Leaders have to focus on change or reform organisations, maintain and communicates high expectations, provide support and recognition, and emotionally move followers to perform well beyond expectations. The extent to which leaders encourage followers is determined by intellectual stimulation so that problems are creatively solved. This happens when leaders encourage their subordinates to search for new solutions to problems (Bass, 1990). Individualized consideration leaders, on the other hand, help followers develop their orientation. This happens when leaders monitor, guide and give regular feedback. Individual consideration is clear when leaders identify their followers' exceptional needs. The way leaders have their vision towards high standards and the way they provide meaningful insights to various work tasks so that future goals are achieved is represented by inspirational Motivation. It is the leaders' capability to clarify and involve successful communication of the vision. Feedback is given and received by leaders, who provide open communication and carefully listen and enhance trust (Bass, 2000). The way leaders behave and inspire followers is represented by idealized influence. Leaders have influence on their followers so that commitment and accomplishment are secured. It occurs when leaders conduct in a moral way. It also represents perceptions of subordinates.

\section{Transformational Leadership Style and Training Experience}

Today, organizational expansion and development are affected by a number of factors. Employee training plays a vital role in improving performance, as well as increasing productivity. This puts companies in the superior positions in order to remain competitive. Therefore, there is a significant difference between the management that trains their subordinates and the management that does not (Nassazi, 2013). Scaduto, Lindsay, and Chiaburu (2008) stressed that in order to improve job performance, leaders should make sure that the skills and behaviors learned and practiced during training are transferred to the workplace, maintained over time, and generalized across contexts. Different styles with each follower imply that leaders are expected to build different exchange relationships with employees at any time. Akhavan and Abu Baker (2009) stated that transformational leaaders can have a significant constructive impact on the transfer of knowledge and skills to their subordinates. The training of extension personnel contributes directly to the development of human resources within extension organizations. Therefore, leaders can have a significant positive impact on the transfer of training to their subordinates. In a nutshell, transformational leaders play an essential role in providing training to their employees, which in turn improves the performance of the employee and the organization as a whole.

\section{Training Experience and Employee Performance}

Training experience is defined as a process of developing work-related knowledge and skills of employees to improve performance systematically (Akhavan \& Abu Baker, 2009). Arthur, Bennett, Edens, and Bell (2003) stated that training can be useful for both the employees and for the organization in terms of increasing their value to their organization, as well as their employability in the local and broader marketplaces. Many organizations are using training and development to attract and keep their most successful employees. Employee training is also related to employee performance. Employee training plays an essential role in improving performance, as well as increasing productivity. Training generates benefits for employees and organizations as well. These benefits relate to performance improvement by developing employees' knowledge, skills, abilities, competencies, and behaviors (Nassazi, 2013; Harrison, 2000). Therefore, training becomes a mechanism to increase performance, and the outcome expectancy of that training is clear through a good relationship with the leader. Evidence of the existing relations between training and employee performance is clear based on the previous literature (Nassazi, 2013). Employee capabilities and professions improve through effective training programs. It does not only change the overall performance of the employees to effectively perform their current jobs, but also improves knowledge, skills, as well as attitudes of employees necessary for the future career and thus contributes to superior organizational performance (Wright \& Geroy, 2001). Despite the importance of training effect on employee 


\section{International Journal of Science and Research (IJSR) \\ ISSN (Online): 2319-7064}

Index Copernicus Value (2013): 6.14 | Impact Factor (2015): 6.391

performance, there is still limited literature on training in less-developed countries (Debrah \& Ofori, 2006).

\section{Methodology}

The analysis of this study was completed on a sample population of 175 academic employees within Colleges of Technology in Oman. This research used SPSS for the descreptive analysis via SPSS and used PLS-SEM for the measurement and the structural models. The MLQ Multifactor Leadership Questionnaire (5x-short) Instrument was adapted by the researcher to measure the transformational leadership style (Bass, 2000). Employee performance as a dependent variable, measured by in role job performance scale adapted from William \& Anderson (Williams \& Anderson, 1991). The mediator variable (training experience) measured by a questionnaire adapted from (Nassazi, 2013).

\section{Results}

The descriptive analysis for all variables was run. Table (1) presents the mean, standard deviations, minimum, and maximum scores calculated for all variables of the present study. Means evaluate the central tendency and standard deviation evaluates variance from the mean. The descriptive of the Constructs are classified according to the six Likert scale which utilized in this study.

Table 1: A summary of descriptive statistics for research variables

\begin{tabular}{|c|c|c|c|c|}
\hline Variable & Mean & $\begin{array}{c}\text { Standard } \\
\text { Deviation }\end{array}$ & Minimum & Maximum \\
\hline Transformational & 4.1853 & 0.87653 & 1.43 & 5.76 \\
\hline Training experience & 4.2806 & 0.99803 & 1.00 & 6.00 \\
\hline $\begin{array}{c}\text { Employee job } \\
\text { performance }\end{array}$ & 4.6206 & 0.70583 & 1.30 & 6.00 \\
\hline
\end{tabular}

Results of PLS-SEM analysis presented the assessment of the measurement model and the strucrural model. The AVE for the constructs ranges from 0.504 to 0.640 , thus exceeding the recommended threshold value of 0.5 . This proved that an adequate convergent validity exists in the measurement model. The value of calculating the square root of the AVE that exceeds the inter-correlations of the construct with the other constructs in the model confirms acceptable discriminant validity. As a conclusion, the measurement model has adequate convergent and discriminant validity.

The structural model shows the relations between latent variables in the research model (Hair et al., 2011). Results showed that the final endogenous construct (employee job performance) has an $\mathrm{R}^{2}$ of 0.231 , which suggests that $23.1 \%$ of the variance in extent of employee performance can be explained by employee training. The Predictive relevance $\mathbf{Q}^{2}$ represents a measure of how well observed values are reconstructed by the model and its parameter estimates (Chin, 1998b). Cross-validated communality and redundancy index greater than 0 are considered acceptable. In this study's path model, large predictive relevance for this construct has been proven by the predictive relevance $\mathrm{Q}^{2}$.

\section{Discussion}

This section discusses the findings of the results based on the data analysis results. It discusses the findings related to the objective of this study, which is to investigate the mediating role of the employees' training experience in the industry between transformational leadership style and employee performance in Colleges of Technology in Oman. It was found that there is a notable direct relationship between transformational leadership and training experience for Colleges of Technology in Oman. The findings of the present study suggested that transformational leaders of Colleges of Technology play active roles in employee development through transferring training to their construction subordinates and graduates. Transformational leaders demonstrate leadership qualities, especially in intellectual stimulation where they challenge old assumptions, mitigate risks, seek followers' ideas, and stimulate followers to be committed and equipped with the most advanced techniques in order to produce competitive graduates for the construction industry. These findings showed a few similarities with research studies conducted by Scaduto, Lindsay, \& Chiaburu (2008) as they stressed that in order to improve job performance, employees must apply the skills and behaviors learned and practiced during training. Akhavan and Abu Baker (2009) also supported the relationship between transformational leadership and employee training. They stated that leaders may positively influence the transfer of training to their subordinates.

Regarding the relationship between employee training and employee job performance, the findings revealed a positive, significant relationship between employee training and employee job performance $(\boldsymbol{\beta}=0.480$ and the $\mathrm{t}$ value of 8.206). According to the results, employee job performance is largely been affected by the training experience of the employees. Findings are consistent with the results of Afshan, Sobia, Kamran, and Nasir (2012), who stressed that both training and development have an impact on employee performance. Additionally, they found that the role of training had a notable influence in the development of employees' skills and the performance of the organization. Alaraimi and Othman (2015) stated that, to produce skillful and qualified workforce in the government and private sectors, technical training programmes have been offered in Oman. The Sultanate of Oman government is developing its citizens to expand and diversify its economy and to meet the industry requirement.

In order to investigate the mediating role of the employees' training experience in the industry between transformational leadership style and employee performance in Colleges of Technology in Oman According to the analysis of the results, the study confirmed that employee training mediated the relationship between construction employee job performance and transformational leadership. This showed that employee training can enhance the function of transformational leadership style on the job performance of the construction employees. It also means that employees' training is critical to the transformational 


\section{International Journal of Science and Research (IJSR) \\ ISSN (Online): 2319-7064}

Index Copernicus Value (2013): 6.14 | Impact Factor (2015): 6.391

leadership style and supports strongly the role of transformational leaders in gaining a high level of employees' performance. The findings are similar to that of Nassazi's (2013), who confirmed that there exists a big difference between leaders, who plan to train their subordinates and leaders, who do not set training as an organizational goal in their planning. Akhavan and Abu Baker (2009) revealed that leaders may greatly influence the transfer of training to their employees, which further prove that leaders have an important role in the training of their subordinates. Therefore, leaders of Omani Colleges of Technology should be aware of their construction employees' training utilizing transformational leadership behaviors to achieve a high level of employee job performance.

\section{Conclusion}

This research leans support to the previous studies undertaken on leadership styles and employee performance. Leadership styles and employee performance formed the model of Bass and Avolio (2000). Based on the important role of employee training towards employee job performance through Full Range Leadership theory, the present study combined the role of employee training and employee job performance to develop a new model. It is done by focusing on the important role of training of the construction employees of Colleges of Technology in Oman, taking into consideration employees' job performance as an indicator of achievable performance which in turn reflects an integrated model of assessment. It is found that employees' training may mediate the leadership behaviours, especially between transformational leadership style and employee job performance. Apart from that, transformational leadership style acts as a predictor of employee training and employees' job performance. Employee training is also a predictor of employee job performance. The findings of this research suggested that Colleges of Technology leaders should embrace the right leadership style and provide practical training to their employees to enhance the performance. Accordingly, employees will perform their tasks better, and that will not reflect only the performance of the employees, but also will enhance their ability to raise the performance of their graduates in the industry.

\section{References}

[1] Abidin, N. Z., \& Powmya, A. (2014). Drivers for green construction in Oman and its future prospects. Middle-East Journal of Scientific Research, 21(6), 929-935.

[2] Afshan, S., Sobia, I., Kamran, A. \& Nasir, M. (2012). Impact of training on employee performance: A study of telecommunication sector in Pakistan. Interdisciplinary Journal of Contemporary Research in Business, 4 ( 6), 646-661.

[3] Akhavan, A., \& Abu Baker, A. (2009). Training, motivation and performance: The case of human resource management in construction projects in Mashhad, Iran. International Journal of Project Management, 27(5), 471-480.
[4] Alaraimi, A., \& Othman, A. (2015). Perceptions of Educational Managers about the Effectiveness of Selected Training Programmes: A Case Study in the Ministry of Education, Oman. IIUM Journal of Educational Studies, 3 (2), 40-74.

[5] AL-Lamki, S. (2002). Higher Education in the Sultanate of Oman: The challenge of access, equity and privatization. Journal of Higher Education Policy and Management, 24 (1), 75-86.

[6] Altbach, P. G. (2011). Leadership for world class universities challenges for developing countries. New York: Routledge.

[7] Arthur, W., Bennett, W., Edens, P. S., \& Bell, S.T. (2003). Effectiveness of training in organizations: A meta-analysis of design and evaluation features. Journal of Applied Psychology, 88, 234-245.

[8] Audu, R., Kamin, Y., \& Saud, M. S. (2013). Acquisition of employability skills in technical vocational education: Necessity for the 21 st century workforce. Australian Journal of Basic and Applied Sciences, 7 (6), 9-14.

[9] Bass, B. M. (1990). Bass and Stogdill's Handbook of leadership: Theory, research, and management application (3rd Ed.). New York: Free Press.

[10]Bass, B. M. (2000). The future of leadership in learning organizations. The Journal of Leadership Studies, 7(3), 18-40.

[11]Bass, B. M. (2005). Leadership and performance beyond expectations (2nd Ed.). New York: Free Press.

[12] Beletskiy, A. (2011). Factors affecting employees' perceptions of the performance appraisal process. Unpublished master's thesis). Hanken School of Economics, Department of Management and Organisation, Helsinki, Finland.

[13]Chin, W. W. (1998b). The partial least squares approach to structural equation modeling. In Marcoulides (Ed.). Modern methods for business research. Mahwah, NJ: Lawrence Erlbaum Associates.

[14] Debrah, Y. A. \& Ofori, G. (2006). Human resources development of professionals in an emerging economy: The case of the Tanzanian construction industry. International Journal of Human Resource Management, 17(3), 440-463.

[15] Ewers, M. C. (2015). Oil, human capital and diversification: the challenge of transition in the UAE and the Arab Gulf States. The Geographical Journal.

[16] Greenslade, J. H., \& Jimmieson, N. L. (2007). Distinguishing between task and contextual performance for nurses: Development of a job performance scale. Journal of Advanced Nursing, 58 (6), 602-611.

[17] Harrison, R. (2009). Employee development. Silver Lakes, Pretoria: Beekman Publishing.

[18] Hair, J. F., Ringle, C. M., \& Sarstedt, M. (2011). PLS-SEM: Indeed a silver bullet. The Journal of Marketing Theory and Practice, 19 (2), 139-152.

[19] Kalbers, L. P., \& Cenker, W. J. (2008). The impact of exercised responsibility, experience, autonomy, and role ambiguity on job performance in public accounting. Journal of Managerial Issues, 20(3), 327292. 


\section{International Journal of Science and Research (IJSR) \\ ISSN (Online): 2319-7064}

Index Copernicus Value (2013): 6.14 | Impact Factor (2015): 6.391

[20] Lamloumi, J. (2013). Entrepreneurship Education in the Arab States. Final Evaluation Report. UNESCOUNEVOC International Centre for Technical and Vocational Education and Training.

[21] Nassazi, A. (2013). Effects of training on employee performance: Evidence from Uganda. (Unpublished doctoral thesis). Business, Economic \& Tourism. University of Applied Sciences.

[22] Saleh, M. S. (2015). Towards sustainable construction in Oman: Challenges \& Opportunities. Procedia Engineering, 118, 177-184.

[23] Scaduto, A., Lindsay, D. \& Chiaburu, D. S. (2008), Leader influences on training effectiveness: motivation and outcome expectation processes. International Journal of Training and Development, 12 (3), 158-170. Doi: 10.1111/j.14682419.2008.00303.

[24] Vigoda-Gadot, E. (2007). Leadership style, organizational politics, and employees' performance: An empirical examination of two competing models. Personnel Review, 36(5), 661-683.

[25] Wang, V. C., \& Berger, J. (2010, April). Critical analysis of leadership needed in higher education. In International Forum of Teaching and Studies, 6(2), 3. American Scholars Press, Inc..

[26] Wang, H., Law, K. S., Hackett, R. D., Wang, D., \& Chen, Z. X. (2005). Leader-member exchange as a mediator of the relationship between transformational leadership and followers' performance and organizational citizenship behavior. Academy of Management Journal, 48 (3), 420-432.

[27] Williams, L. J., \& Anderson, S. E. (1991). Job satisfaction and organizational commitment as predictors of organizational citizenship and in-role behavior. Journal of Management, 17(3), 601-617.

[28] Wright, P., \& Geroy, D. G. (2002). Changing the mindset: The training myth and the need for wordclass performance. International Journal of Human Resource Management, 12(4), 586-600

Volume 5 Issue 6, June 2016 www.ijsr.net 